\title{
Corrigendum: Adrenergic-mediated loss of splenic marginal zone $B$ cells contributes to infection susceptibility after stroke
}

\author{
Laura McCulloch, Craig J. Smith \& Barry W. McColl
}

Nature Communications 8:15051 doi: 10.1038/ncomms15051 (2017); Published 19 Apr 2017; Updated 18 Aug 2017

The affiliation details for Barry W. McColl are incorrect in this Article. The correct affiliation details for this author are given below:

The Roslin Institute and R(D)SVS, University of Edinburgh, Easter Bush, Midlothian EH25 9RG, UK.

UK Dementia Research Institute, University of Edinburgh, Edinburgh Medical School, 47 Little France Crescent, Edinburgh EH16 4TJ, UK.

(c) Open Access This article is licensed under a Creative Commons Attribution 4.0 International License, which permits use, sharing, adaptation, distribution and reproduction in any medium or format, as long as you give appropriate credit to the original author(s) and the source, provide a link to the Creative Commons license, and indicate if changes were made. The images or other third party material in this article are included in the article's Creative Commons license, unless indicated otherwise in a credit line to the material. If material is not included in the article's Creative Commons license and your intended use is not permitted by statutory regulation or exceeds the permitted use, you will need to obtain permission directly from the copyright holder. To view a copy of this license, visit http://creativecommons.org/licenses/by/4.0/

(C) The Author(s) 2017 